\title{
SUSTAINABILITY ASSESSMENT OF JARI VALLEY - AMAPÁ - AMAZON: LARANJAL AND VITÓRIA DO JARI
}

\author{
José Francisco de Carvalho Ferreira \\ Jacklinne Matta Corrêa \\ Jodival Maurício Costa
}

${ }^{I}$ Regional Development, Federal University of Amapá (UNIFAP) Macapá/AP - Brazil

II Regional Development, Federal University of Amapá (UNIFAP) Macapá/AP - Brazil

Geography, Federal University of Amapá (UNIFAP) Macapá/AP - Brazil
Abstract: Problems of regional/local nature requires the use of tools that analyze processes related to the development model compatible with the principles of sustainable development. In this context, research on sustainability gains space in the debate on development, from the use of indicators. Although scarce in the State of Amapá, sustainability assessments can recommend the assessment of the impacts that emerge around large private projects in the Amazon. In this sense, this article seeks to assess the levels of sustainability of Laranjal and Vitória of Jari, using indicators that incorporate several dimensions and aspects. Methodologically, indicators collected from official sources will be used, treated and standardized by their own methodology, which will result in a score that will mark the municipal progress towards sustainable development. The results indicate that the two municipalities have weak performances that compromise their municipal sustainability and the direction to Agenda 2030.

Keywords: Sustainability assessment. Sustainable Amazon. Laranjal of Jari. Vitória of Jari.

São Paulo. Vol. 23, 2020

Original Article

DOI: http://dx.doi.org/10.1590/1809-4422asoc20180308r2vu2020L4AO 


\section{INTRODUCTION}

The assessment of municipal sustainability at a regional/local level is still very recent, as is the emergence of the concept of sustainable development. However, when it comes to the Amazon, academic works that reflect upon municipal sustainability are even more recent, although some have appeared in the last 5 years, showing that, even for such a vast territory, populated to fill demographic gaps and for security reasons, but also because it is object of national and international capital due its abounding resources, it is important to discuss sustainability.

The Jari Valley, which is the subject of our analysis herein, includes Laranjal do Jari and Vitória do Jari in the State of Amapá and Almeirim in the State of Pará. However, this article will consider only the municipalities of the State of Amapá, given the proximity with and importance of the Industrial Complex of the Jari valley for the formation of the State of Amapá (Federal Territory since 1943, has become a state in 1989).

This paper intends to assess the sustainability of two municipalities of the State of Amapá, in the Northern Amazon, using indicators. The specificity of these two municipalities, Vitória and Laranjal do Jari, is that their development is based on projects arising from central government policies, open to private capital.

The starting point that triggered this research was the idea of studying the influence that these large developments have or may have in the sustainability of these two municipalities, in the countryside of the State of Amapá. Does the implementation of developments projects within the logic of national planning, favoring the action of national and international capital in the Amazon, promoted an integrated and consistent development in the two municipalities of the State of Amapá?

In this article, after this introduction, materials and methods are presented, detailing the methodological procedures that support this sustainability assessment. Then, the municipalities of Vitória and Laranjal do Jari are presented. Given that the reflection of this paper revolves around the concept of sustainable development and its indicators, item 4 reflects these sustainability indicators and their relation with the concept of sustainable development. In item 5, the results of this paper are presented and some considerations are made about the results of each dimension, starting from the performance of indicators and their respective variables. The article ends with final considerations and bibliographic references.

\section{MATERIALS AND METHODS}

Materials used for this paper are mainly based on statistical data from various official sources such as IBGE, DATASUS, INPE, FINBRA, ATLAS BRASIL, ANATEL, ÍNDICE DE PROGRESSO SOCIAL (INDEX OF SOCIAL PROGRESS), MINISTÉRIO DA SAÚDE (MINISTRY OF HEALTH), PROGRAMA CIDADES SUSTENTÁVEIS (SUSTAINABLE CITIES PROGRAMME), as well as bibliographic materials, both national and international. 
Methodologically, this paper is based on works by Ferreira (2012, 2013), Tostes and Ferreira $(2014,2017)$, and considers, among others Siena (2002), Silva, Amin and Nunes (2015), Ribeiro (2002), Kerk and Manuel (2008), Silva, Souza and Leal (2012), Bellen (2004), Braga et al. (2003, 2004), Kemerich, Ritter and Borba (2014), Santos et al. (2014), Vale, Toledo and Vieira (2018), taking as a start point a more comprehensive and systemic view, which supplant the "[...] hegemony of the economic dimension" (GUIMARÃES; FEICHAS, 2009, p. 213).

In the sustainability assessment, some methodological issues are addressed in order to reach a value that incorporates the most relevant aspects, to analyze the progress of a given territory towards sustainable development, issues that will be addressed below.

One of these issues is the standardization of indicators and their variables, since they have different nature and their own metrics (SIENA, 2002). Thus, we need to use a procedure that allows using them in the same unit of measurement. This procedure contemplates the use of 2 side by side scales, one that refers to the indicator and that obeys its nature, and another a standard scale. Both are subdivided into 5 classes, the first one according to the nature of the indicator and the second from 0 to 100, depending on the positive or negative relationship that the indicator has with the score composition ${ }^{1}$.

The use of two side by side scales makes possible compare the values of each indicator of the municipalities with the national values, local, national or international goals, when and if any (see SUSTAINABLE CITIES PROGRAM, 2012). The combination of these two scales allows the standardization of the indicators, using two calculation formulas.

Formula 1: Score $=$ top of standard scale $-\{[$ (indicator value - minimum indicator band value $) \div$ (maximum indicator band value - minimum indicator band value) $] \times 20\}$.

Formula $2:$ Score $=\{[$ (indicator value - minimum indicator band value $) \div($ maximum indicator band value - minimum indicator band value) $]$ x 20$\}+$ standard scale base band

The two scales are arranged so that there is a matching between them. The first one is taken into account considering the goals founded, or taking national mean values as a reference for that indicator, or even using the maximum and minimum values of each indicator, those found for the country or even international values.

In order to have greater cohesion and uniformity in the criteria, when there is a target value or, in its absence, the average national value, the target value will be set at 80 in the standard scale. The best situation will be scored 0 or 100, depending on the positive or negative correlation of the indicator in the construction of the score, as noted.

1- The standard scale between zero and one hundred, depending on the positive and negative relationship that the indicator has for the score, it considers, in quali-quantitative terms, the following reference: $0-20=$ unsustainable; $20-40$ $=$ almost unsustainable; $40-60=$ intermediate; $60-80=$ almost sustainable; $80-100=$ sustainable. 
Another relevant issue concerns the scope of the assessment, i.e., the reach of reference values. It can be local, national or even international. It is understood that using national average values, minimum and maximum values of indicators at national level and according to local, national and international standards, based on their existence and availability, may bring more insightful results, allowing to observe the performance of the municipalities of the Jari Valley in a wider context, beyond the state of Amapá or the states of the Amazon.

In this context, we took into account the document "Sustainability Goals for Brazilian Cities" (SUSTAINABLE CITIES PROGRAMME, 2012), an important national reference, with regard both to indicators and goals and to standards. Another point of reference was the Index of Social Progress of the Amazon (SANTOS et al., 2014).

Regarding the relevance of indicators, this assessment assumes that the indicators have equal weights in the composition of the final score. However, in some methodologies, the authors attribute weights, according to their understanding of the importance of each indicator, which is common in several indexes (SIENA, 2002; SILVA; AMIN; NUNES, 2015). This paper assumes that all indicators have equal weights, since everything is understood to be interconnected and interdependent within the scope of a systemic view that should base an equally systemic planning (BARCELLOS; BARCELLOS, 2004).

The procedure is simple and is intended to be practical. The final value obtained for each dimension is the result of the mean of the sub-dimensions, which in turn are the result of the simple mean of the indicators that compose it, which are the result of the simple mean of the variables composing them. The final result will be presented by dimension, but it could also be by sub-dimension and by indicator, allowing different analysis, either by municipality, or by comparing them with other municipalities in the state/country.

\section{THE JARI VALLEY}

The Jari Valley, located on the border between the states of Amapá and Pará, is home to the cities of Laranjal do Jari and Vitória do Jari, in Amapá, and Almerim, Pará (CHAGAS, 2015). The emergence of the cities of Laranjal do Jari, Vitória do Jari and the District of Monte Dourado are closely related to the deployment of industrial and mineral projects and large investments made by private entrepreneurs (PORTO, 2003; TOSTES, 2009).

These developments have leveraged a significant demand for urban infrastructure to house skilled employees assigned to the industrial complex, giving origin to the Monte Dourado District, a region that was favored by an exogenous planning policy that followed the pattern of North-American cities and can now count on an infrastructure and urban services that stand out in the Amazonian landscape (TOSTES, 2012).

On the other hand, a large contingent of people was attracted to the region in search of jobs and opportunities, giving origin to the cities of Amapá, Laranjal do Jari and Vitória do Jari, previously known as Vila Beiradão and Beiradinho, respectively. The 
process of spatial occupation was marked by the non-compliance with social guarantees.

Therefore, the region of the Jari Valley, since the 1970's, is directly affected by the Jari Industrial Complex ${ }^{2}$ and has become a major destination of migration flows in the Amazon (PAIXÃO, TOSTES, 2010). In addition to the historical economic relation, preservation approaches enhance the condition of spatial isolation, low density and large forest areas (CHAGAS, 2015). Another remarkable feature of the region is the dynamics of formation of cities on the Amapá side, which is the mostly populated wetland region in the Amazon (TOSTES, 2009; PAIXÃO, 2008).

The municipalities of Laranjal do Jari and Vitória do Jari are located in the southern edge of Amapá (Figure 1). In both cities, the economy is essentially based on mineral extraction and services. In terms of population and territorial dynamics, according to IBGE (2018), the municipalities have an estimated population of 65,051 inhabitants, with a low demographic density, dispersed throughout an area of 33,291,977 km².

Figure 1 - Location map of the Jari Valley region

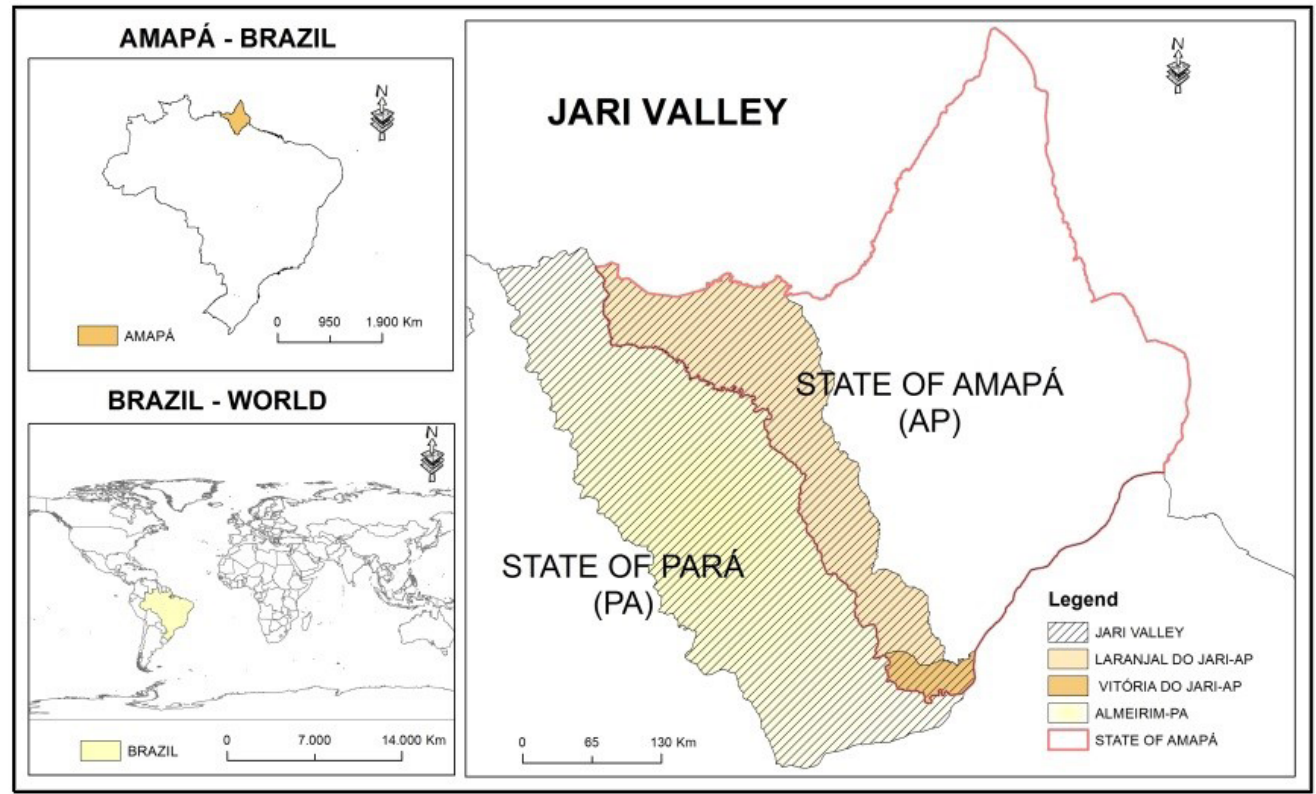

Source: MMA (2018). ArcGis 10.1. Made by the Authors.

On an economic and environmental level, the municipalities are essentially based on extractive activities, both plant and mineral, and in the service sector (FILOCREÃO, 2007). Due to the strong preservationist policy, their territories are home for several protected areas: Jari Eco-Station; Extractive Reserve of the Cajari River; Iratapuru River 
Sustainable Development Reserve; Tumucumaque Mountains National Park, in addition to the Indigenous land of Waiãpi and Indigenous Park of Tumucumaque (RABELO et al., 2004; CHAGAS, 2015).

\section{SUSTAINABLE DEVELOPMENT: WHAT ARE WE MEASURING?}

The use of indicators to measure the development process is not new, although its use in a broader scope, beyond a purely economic approach, dates back to the 1990s. It started to be better known and disclosed with the emergence of the Human Development Index (HDI) (GUIMARÃES; FEICHAS, 2009), which is widely used till nowadays.

However, at the pinnacle of the May 1968 Movement, which demanded social and environmental changes, two different groups of stakeholders arise: on the one hand, there was an international institutional movement, which gave rise to the UN Conference on the Human Environment, also known as the Stockholm Conference, in 1972, and, on the other hand, scientists and businessmen, concerned with the future of development and its harmful environmental and social consequences. It marks the emergence of the so-called Club of Rome, which publishes the report "Limits to Growth" (1972), one of the most important references of this change.

With the Stockholm Conference, under the aegis of the United Nations, discussions begin to revolve around a development tripod based on environment, society and economy, with the purpose of considering a broader and more comprehensive development process. This is how the concept of Eco-development coined by Ignacy Sachs arises, followed later by the concept of sustainable development, introduced by the report "Our common future", also called the Brundtland Report, in 1987.

After 1987, the concept is formally and widely spread in Rio 92 (United Nations Conference on Environment and Development). There are several critical reflections on the Brundtland Report and the concept of sustainable development established in Rio 92, which, although interesting, do not fit into this article. However, for the purposes of this article, it is interesting to address the famous document drafted in the Rio 92, the Agenda 21.

Chapter 40 of Agenda 21 is about the need to gather information and data, at all scales, to make informed decisions, stating "[...] the status and trends of the planet's ecosystem, natural resource, pollution and socio-economic variables. [...]" (CNUMAD, 1995, p. 465).

On item 40.4, we read that "Commonly used indicators such as the gross national product (GNP) and measurements of individual resource or pollution flows do not provide adequate indications of sustainability." (CNUMAD, 1995, p. 465-466). This leads us do conclude that it is necessary to develop indicators of sustainable development that will support, with soundness, decision-making at all levels and contribute to an integrated understanding of the relation between the environment and development.

According to Agenda 21, it was necessary to develop and promote the global use 
of sustainable development and to improve the collection and use of data (CNUMAD, 1995, p. 466). Item 40.8 states what the indicators should measure. So, according to it, countries should

[...] carry out inventories of environmental, resource and developmental data, based on national/global priorities for the management of sustainable development. [...] data-collection activities, including those of Earthwatch and World Weather Watch, need to be strengthened, especially in the areas of urban air, freshwater, land resources (including forests and rangelands), desertification, other habitats, soil degradation, biodiversity, the high seas and the upper atmosphere. [...] special attention needs to be paid to such areas as demographic factors, urbanization, poverty, health and rights of access to resources, as well as special groups, including women, indigenous peoples, youth, children and the disabled, and their relationships with environment issues. (CNUMAD, 1995, p. 467).

It is in this context that the concept of sustainable development has been deepened, beyond the definition of the Brundtland Report, confirmed in Rio-92, which defines it as one "that meets the needs of the present without compromising the ability of future generations to meet their own needs." (CMMAD, 1991, p. 46), in order to gather features that contribute to a more advanced and integrated stage of the development process.

In the international literature there are many definitions that emphasize aspects that are not always coincident, but which contribute to promote the Agenda 21 in terms of indicators. Thus, although some references demonstrate complexity, emptiness and inaccuracy (GIBSON et al., 2005; MAWHINNEY, 2005), many authors use the concept to carry out sustainability assessments at all levels, as is the case of this article, in an attempt to materialize the concept (FERREIRA, 2012).

In this context, if we analyze authors that reflect upon and discuss the concept of sustainable development, it is possible to outline some of the main characteristics that support a better understanding of the concept and its possible uses.

Kerk and Manuel (2008), based on the definition of the Brundtland Report, look for the most relevant aspects of this definition to which they add others, in line with their attempt to assess sustainability by comparing countries.

The authors begin by pointing out that many people believe that the idea of sustainability focuses mainly on the depletion of resources; others consider that sustainability also covers pollution, nature conservation and other environmental and ecological aspects. Others even include aspects related to the quality of human life, the human wellbeing. The authors point out that, from the anthropocentric point of view, sustainability comprises the three elements below:

[...] depletion of resources, in order not to leave future generations empty-handed; environmental and ecological aspects, in order to enable present and future generations to live in a clean and healthy 
environment, in harmony with nature; quality of life, in order to ensure human well-being for present and future generations. (KERK; MANUEL, 2008, p. 229).

In this regard, the aforementioned authors take a significant step towards thinking about a sustainable society and its main characteristics. A sustainable society is one that meets the needs of the present generation; does not compromise the ability of future generations to meet their own needs; in which each human being has the opportunity to develop itself in freedom, within a well-balanced society and in harmony with its surroundings. Thus, every human being is able to develop itself in a healthy manner and to obtain a proper education, live in a clean environment, live in a well-balanced and safe society, use non-renewable resources in a responsible manner and contribute to a sustainable world.

Ferreira (2012) highlights several aspects: sustainable development is a process of transformation; which occurs harmoniously in many dimensions; aims an integral human promotion, full citizenship and social equity; promotes peace and security, a healthy and ecologically balanced environment and considers both present and future generations.

Martins (2004), in turn, highlights the satisfaction of basic needs, equity and social justice, future generations, respect for the self-determination of peoples, respect for cultural diversity and maintenance of environmental assets, citizenship and new consumption patterns, in harmony with nature.

According to the subjects under chapter 40 of Agenda 21, although the number and type of indicators to be used is still discussed, it is common sense that measures should be taken to assess the progress towards sustainable development (BOSSEL, 1999; RAMOS, 2009), through the use of indicators.

The indicators themselves, according to the literature, must meet certain criteria: they must be relevant and perceptible, transparent, measurable, available, reliable, recent, frequently updated and not excessive; also, they cannot overlap and must represent international consensus and allow comparisons (BOSSEL, 1999; SPANGENBERG et al., 2002; ROLDÁN; VALDÉS, 2002; BRAGA et al., 2004; KERK; MANUEL, 2008; MASCARENHAS et al., 2010).

This article thus covers a wide bibliography on indicators and methodologies for assessing sustainability, whether at local, regional, national and international level, as well as many definitions of sustainable development ${ }^{3}$, which support a wide range of issues that translate into indicators, following the indications of Chapter 40 of Agenda 21.

\section{RESULTS AND DISCUSSION}

In this sustainability assessment, 4 dimensions, 14 sub dimensions, 34 indicators

3 - See, between others, Siena (2002); Roldán and Valdês (2002); Spangenberg et al. (2002); Braga et al. (2004); Wheeler (2004); Mawhinney (2005); Roberts (2006); Silva (2006); Kerk and Manuel (2008); Ramos (2009); Mascarenhas et al. (2010); Silva, Souza and Leal (2012); Programa Cidades Sustentáveis (2012); Ferreira (2012, 2013, 2017); Boff (2013); Santos et al. (2014). 
and 65 variables were used, as shown in table 2 .

Table 1 brings an overview of the results, indicating the average scores of each municipality by dimension.

Table 1 - Result of the Sustainability Assessment of the municipalities of Laranjal and Vitória do Jari

\begin{tabular}{c|l|l} 
Dimension/Municipality & Laranjal do Jari & Vitória do Jari \\
Political / Institutional & 29,58 & 14,08 \\
\hline Economic & 45,52 & 39,16 \\
\hline Environmental & 45,54 & 33,97 \\
\hline Sociocultural & 72,40 & 63,52 \\
\hline Average Score & 48,26 & 37,68 \\
\hline
\end{tabular}

Source: The Authors, 2018

From a global perspective, it can be seen that the two cities do not reach 50 points. On the other hand, although both have low scores, Laranjal do Jari scores higher than Vitória do Jari in all dimensions. It should also be noted that it is in the PoliticalInstitutional dimension and socio-cultural dimension that municipalities have the worst and the best performance, respectively.

When we observe data on Vitória do Jari (figure 2), it is remarkable that this municipality has a clear weakness in the institutional political dimension, as it scored only 14.08 points. Analyzing it in detail, one notices that such municipality has very few public servers with higher education degree, virtually no investment expenses, financial liabilities that are almost twice as high as its assets, a heavy bureaucratic structure for its size with even more servers than Laranjal do Jari. 
Figure 2 - Vitória do Jari Sustainability Assessment Overview, by dimension

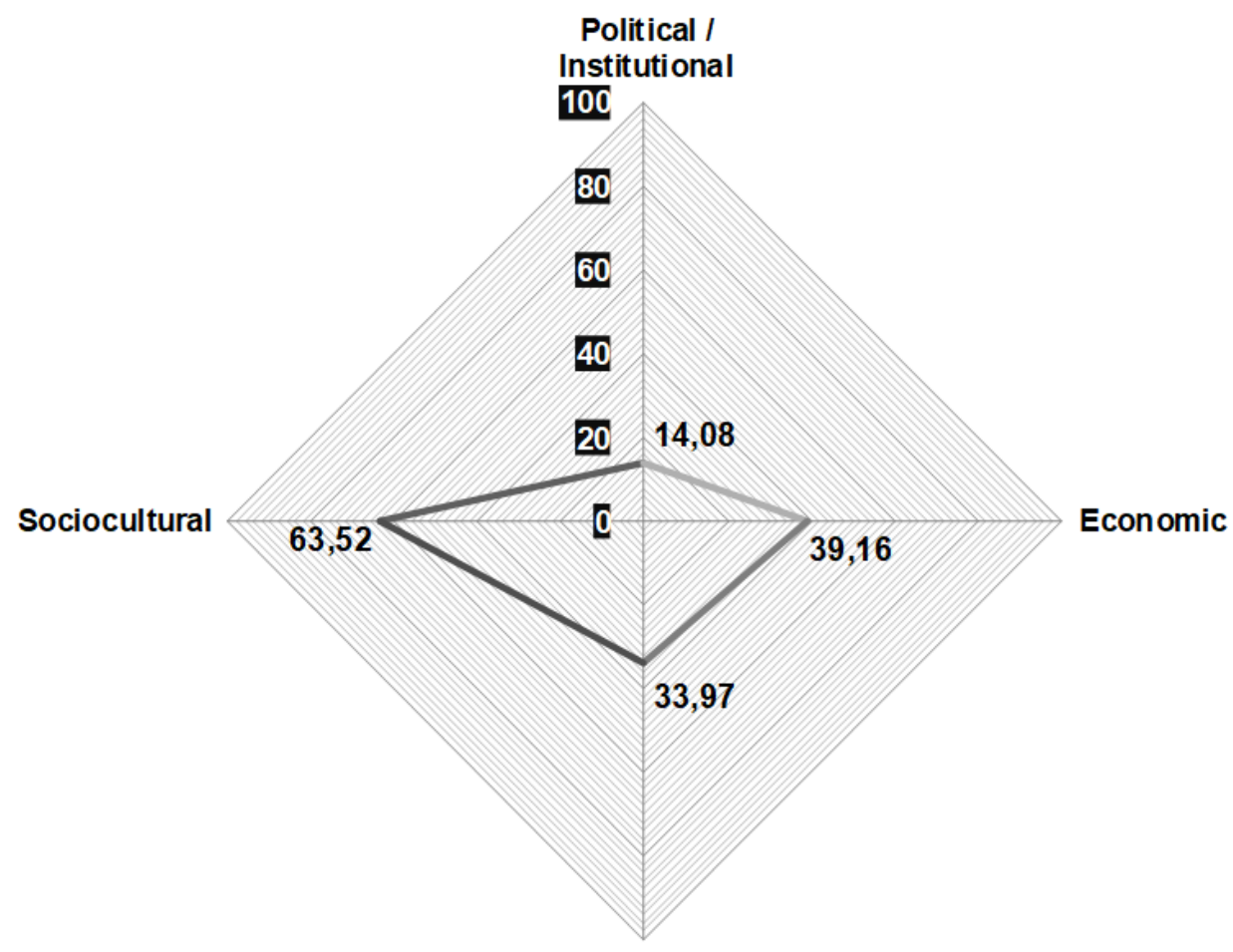

Environmental

Source: The Authors, 2018

The existence of organizations representing Civil Society and joint municipal councils are meaningless. The revenue allocated to personnel expenses is relatively high, hence the low score. Features of the environment, which includes street signs, public lighting, pavement, sidewalk, curb/guide, manhole, ramp for wheelchair and afforestation, also had a quite low value, scoring only 26.48 points.

The environmental dimension has also shown to be weak in the assessment. Having scored only 33.97 points, its poor result is mainly, but not exclusively, due to the issue of solid waste. When it comes to waste, one notices that it does not go through any treatment or transformation, is not collected on a selected basis, and is entirely sent to the city's landfill (PAIXÃO, 2016). On the other hand, water waste is also substantial, surpassing 4/5 of all the distributed water.

"Open sewage" and "households with access to the sewage system or to a septic tank" are the other variables that contribute least to this dimension, indicating important local concerns. In contrast, "households with direct or indirect garbage collection services", "accumulated garbage" and "emissions of carbon monoxide per vehicle for each 
inhabitant" are the variables that contribute most positively to this dimension.

With regard to the economic dimension, with 39.16 points, among the variables that contribute least to this dimension are "Households in poverty", with 19.29 points, and the "Unemployment Rate", which is one of the highest in the country, with only 24.2 points. Concurrently, another highlight is the variable "Vulnerable to poverty", with relatively high scores, but showing a situation of extreme weakness, since it implies a high percentage of people living on less than $\mathrm{R} \$ 255$ per month in 2010 (66.9\%), with only 16.4 points.

Contradicting this weakness somehow, the variable "Women between 10 and 17 with children" is the one that performed best in this dimension, with 95.5 points, and the variable "Variation on formal job vacancies 2008-2010", which scored 78.08 points, probably because this municipality relies on a foreign capital company, which is supposed to leverage the economy. However, in the ensemble of dimensions, the economic one has a modest performance, still far from the average of 50 points.

The socio-cultural dimension is the one scoring highest points. With 63.52 points, this dimension is granted a score that is more than 20 points higher than the economic dimension, which is the second highest in the four dimensions context. Vitoria do Jari does not have any hospital beds, which, when it comes to the Amazon, means that citizens need to travel to a city that provides health care services, in this case, Macapá, the state capital.

However, when we look at the variables regarding mortality, this does not necessarily seem to be an issue, since the scores, which indicate their performance in the national context, show a more than satisfactory performance. As an example, values of the variables "Death by malnutrition", with 87.39 points, "Maternal mortality", 96.40 points and "Mortality by infectious diseases", with 95.7 points, all of them in the highest point range (80-100 points).

It should be noted that, as mentioned in the methodology, this assessment is based, among others, on Brazil's minimum and maximum values. Thus, although the municipalities at issue are not always in the best situation, they perform better in most of the variables that make up the socio-cultural dimension. Let's take, for example, the variable "maternal mortality". The value for Vitória do Jari is 112.6 deaths (per 100 thousand inhabitants), ranking fifth among the 16 municipalities in Amapá. Comparing Vitória do Jari with the rest of the country, pondering the worst value of 3215 in Santa Rita do Tocantins, Vitória do Jari scored much higher, which is explained exactly by what has just been mentioned.

We could use the same reasoning for the variables "Number of deaths by firearm", "Violence against women", "Mortality by infectious diseases", "Death by malnutrition", "Suicide", "Mortality by chronic diseases" and "Mobile Internet data connection", all of them scoring above 80 points.

The worst performances of this dimension are the variables "Malnutrition", with only 41.6 points; "Child Mortality", with 40.8 points; "People aged 25 and more years with higher education", with 24.1 points; "Achievement index in basic education", with 
33 points; "Precarious households", with 23.14 points and "Cultural assets", with 29.41 points, indicating several aspects that need greater investment.

As for Laranjal do Jari (figure 3), with an overall average score of 48.26 points, it follows the same trend observed in Vitória do Jari, with the lowest score for the politicalinstitutional dimension and the highest score for the socio-cultural, although the environmental dimension has had a slightly higher score than the economic dimension, assuming a different position from Vitória do Jari. However, the total values of the dimensions in Laranjal do Jari are higher than in Vitória do Jari.

Figure 3 - Laranjal do Jari Sustainability Assessment Overview, by dimension

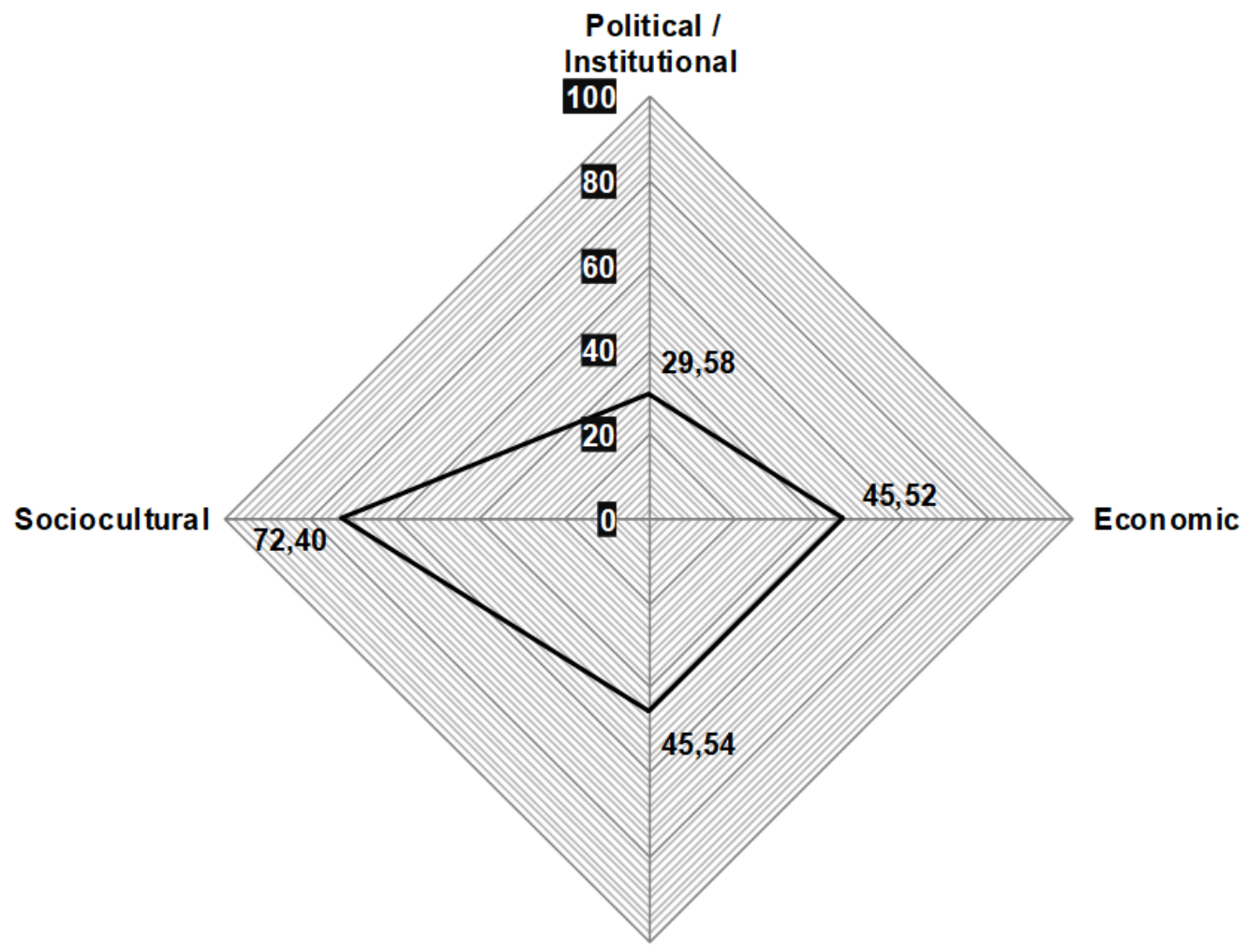

\section{Environmental}

Source: The Authors, 2018

Figure 3 points out that, as in Vitória do Jari, the greatest weaknesses are found in the institutional-political dimension, with 29.58 points, yet twice as high as Vitória do Jari. In general, if we disregard the variables "Number of servers per thousand people" and "Cash Sufficiency", which most contribute positively to the overall value of this dimension, the other variables have very low values. However, with meager revenues, modest investments, few servers with a higher education degree, with almost $60 \%$ of the income committed to personnel expenses, few organizations representing the Organized Civil Society and with fragile urban features, Laranjal do Jari still has much to improve 
in this dimension, as it does not even reach the average score of 50 points.

We have only 3 variables scoring more than 50 points: "Unemployment rate" (55.9 points); "Creation of formal job vacancies 2008-2010" (65.17 points) and "Average GDP growth in the last three years (57.79 points). On the other hand, the variables "Women aged 10 to 17 with children", with only 28.9 points, "Households in poverty", with 31.01 points, "Vulnerable to poverty", which reaches over half of the population, with 33.8 points, and "Per capita GDP" with only 32.65 points are the main negative highlights.

Comparing both cities within this dimension, one notices that Vitória do Jari scores higher in the "Economic Dynamism" indicator, perhaps due to the Jari Cellulose Project and Kaolin exploration, within the Jari Industrial Complex, which is responsible for this dynamics. On the other hand, they both are highly vulnerable, with 53\% (Laranjal do Jari) and $66.9 \%$ (Vitória do Jari) of their population living with less than $\mathrm{R} \$ 255$ per month, which creates a situation of deep weakness. This weakness is even seen in the city's landscape, for, as we know, Laranjal do Jari has long been considered the largest "riverside slum" in the world.

As for the environmental dimension, it should be pointed out that such dimension has a better performance in Laranjal do Jari than in Vitória do Jari, although they both score less than half the total score (50 points). With an average of 45.54 points, it features as the second best dimension of Laranjal do Jari, although with a slight difference over the economic dimension.

When we pay attention to the variables of the indicator "Basic Sanitation", we can notice that "Households with access to the general sewerage network or septic tank" is the weakest of them, with only 8.7 points, which can be evidenced by the fact that a large share of the population lives in stilt houses.

"Water waste", as well as "average per capita water consumption" are two other variables that contribute little to the environmental dimension. Moreover, considering the 110 liters per day recommended by the United Nations as an average expenditure to meet a person's needs, it should be noted that Laranjal do Jari records an average of 160 liters/person/day, which is $45.45 \%$ more than recommended. In contrast, it is important to highlight that in Vitória do Jari, the value of the variable is $27.64 \%$ lower than what is recommended by the UN, therefore, such city scored higher than Laranjal do Jari.

In the variables related to solid waste, it should be noted that Laranjal do Jari still has a dump, contrary to the provisions of the National Solid Waste Policy (Law No. $12.305 / 10$ ), which recommends an alternative for dumps until the end of 2014. Well, we are in 2018 and solid waste is still dumped in landfills, is not recovered at all, whether as energy or as fertilizer, is not recycled, because, in fact, there is also no selective collection, $20.66 \%$ of the overall solid waste results in an accumulation, which demonstrates how precarious the current situation is. In addition to this devastating scenario, we have a 70.3\% rate of "Open sewage", thus drastically worsening the situation of weakness.

The description of the environmental variables runs counter the fact that $94.92 \%$ of the territory of Laranjal do Jari is a "protected municipal territory". Considering what was referred to in the item describing our object, about Indigenous Territories and 
Conservation Units, it can be seen that only $5.08 \%$ of the territory corresponds to the urban area of Laranjal do Jari. Therefore, this might lead us to conclude that the main environmental issues and, by inference, economic and social issues, are mostly found in the urban area of Laranjal do Jari.

There should also be a reference to the "Area dedicated to organic farming" which, in both municipalities at issue, scored 0 . This variable, placed within the "Biodiversity" indicator, was included due to its relevance both for food security and food self-sufficiency, in such a way to reduce external dependence, and for the protection of biodiversity, with farming practices that do not harm any species or the soils. Because we believe in the potential of the Amapá state and, therefore, in the potential of its municipalities, this variable was also included.

Such as in Vitória do Jari, in Laranjal do Jari the social-cultural dimension is the one that performs best, with 72.40 points. If we analyze only the variables that scored less than 50 points, we will have "Health care facilities", with 18 points, "Hospital beds", with 38.1 points, "Child Mortality", with 46.4 points, "People aged 25 and more years with higher education", with 32.6 points, the "achievement index in basic education IDEB ", with 36.5 points, which, altogether, indicate that education and health are the indicators that most need to be paid attention to by Public Authorities.

Having scored more than 50 points, the other variables need to be followed and enhanced to reach the "Sustainable" status (from 80 to 100 points), since the average of all variables and indicators exceeds 70 points (72.40), which means an "Almost Sustainable" status (from 60 to 80 points). 


\begin{tabular}{|c|c|c|c|c|c|}
\hline DIMENSION & SUB-DIMENSION & INDICATORS & VARIABLES & $\begin{array}{l}\text { Laranjal do } \\
\text { Jari }\end{array}$ & Vitória do Jari \\
\hline \multirow{9}{*}{$\begin{array}{l}\text { Political -Insti- } \\
\text { tutional }\end{array}$} & \multirow{2}{*}{ Participation } & Social Capital & Existence of Organizations Representing Civil Society (\%) & 22,53 & 16,09 \\
\hline & & Governance & Existence of Joint Municipal Councils (Ner) & 41,18 & 17,65 \\
\hline & \multirow{2}{*}{$\begin{array}{l}\text { Administrative } \\
\text { Management }\end{array}$} & \multirow{2}{*}{$\begin{array}{l}\text { Functional } \\
\text { Frame Quality }\end{array}$} & Number of servers per thousand inhabitants (\%o) & 61,5 & 10,2 \\
\hline & & & Servers with a higher education degree (\%) & 23,55 & 3,58 \\
\hline & \multirow{4}{*}{$\begin{array}{l}\text { Financial Manage- } \\
\text { ment }\end{array}$} & $\begin{array}{l}\text { Capacity ode } \\
\text { collection }\end{array}$ & Own Income Over Total Income (\%) & 3,63 & 4,47 \\
\hline & & $\begin{array}{l}\text { Capacity of } \\
\text { investment }\end{array}$ & Investment expenditures over Expenditure Incurred (\%) & 16,47 & 7,3 \\
\hline & & \multirow{2}{*}{ Financial Heath } & Cash sufficiency (\%) & 72,87 & 21,96 \\
\hline & & & Total Net Revenue Allocated to Personnel Expenses (\%) & 40,7 & 23,04 \\
\hline & Urban Management & Urban features & Features of the urban environment (\%) & 26,2 & 26,48 \\
\hline \multirow{9}{*}{ Economic } & \multirow{9}{*}{$\begin{array}{l}\text { Economy and } \\
\text { income }\end{array}$} & Income level & Per capita income $(\mathrm{R} \$)$ & 43,6 & 31,2 \\
\hline & & Unemployment & Unemployment rate -10 years or more (\%) & 55,9 & 24,2 \\
\hline & & Inequality & Gini Coefficient (0-1) & 45,0 & 42,0 \\
\hline & & \multirow{3}{*}{$\begin{array}{l}\text { Vulnerability/ } \\
\text { equity }\end{array}$} & Households in poverty (\%) & 31,01 & 19,29 \\
\hline & & & Vulnerable to poverty (\%) & 33,8 & 16,4 \\
\hline & & & Women aged 10 to 17 with children (\%) & 28,9 & 77,3 \\
\hline & & \multirow{3}{*}{$\begin{array}{l}\text { Economic } \\
\text { dynamism }\end{array}$} & Creation of formal job vacancies 2008-2010 ( $\Delta \%)$ & 65,17 & 78,08 \\
\hline & & & GPD average growth in the last three years $(\Delta \%)$ & 57,79 & 69,68 \\
\hline & & & Per capita GPD $(\mathrm{R} \$)$ & 32,65 & 34,70 \\
\hline Environmental & Environment & Basic sanitation & $\begin{array}{l}\text { Households with direct or indirect garbage collection } \\
\text { services }(\%)\end{array}$ & 60,1 & 65,9 \\
\hline
\end{tabular}




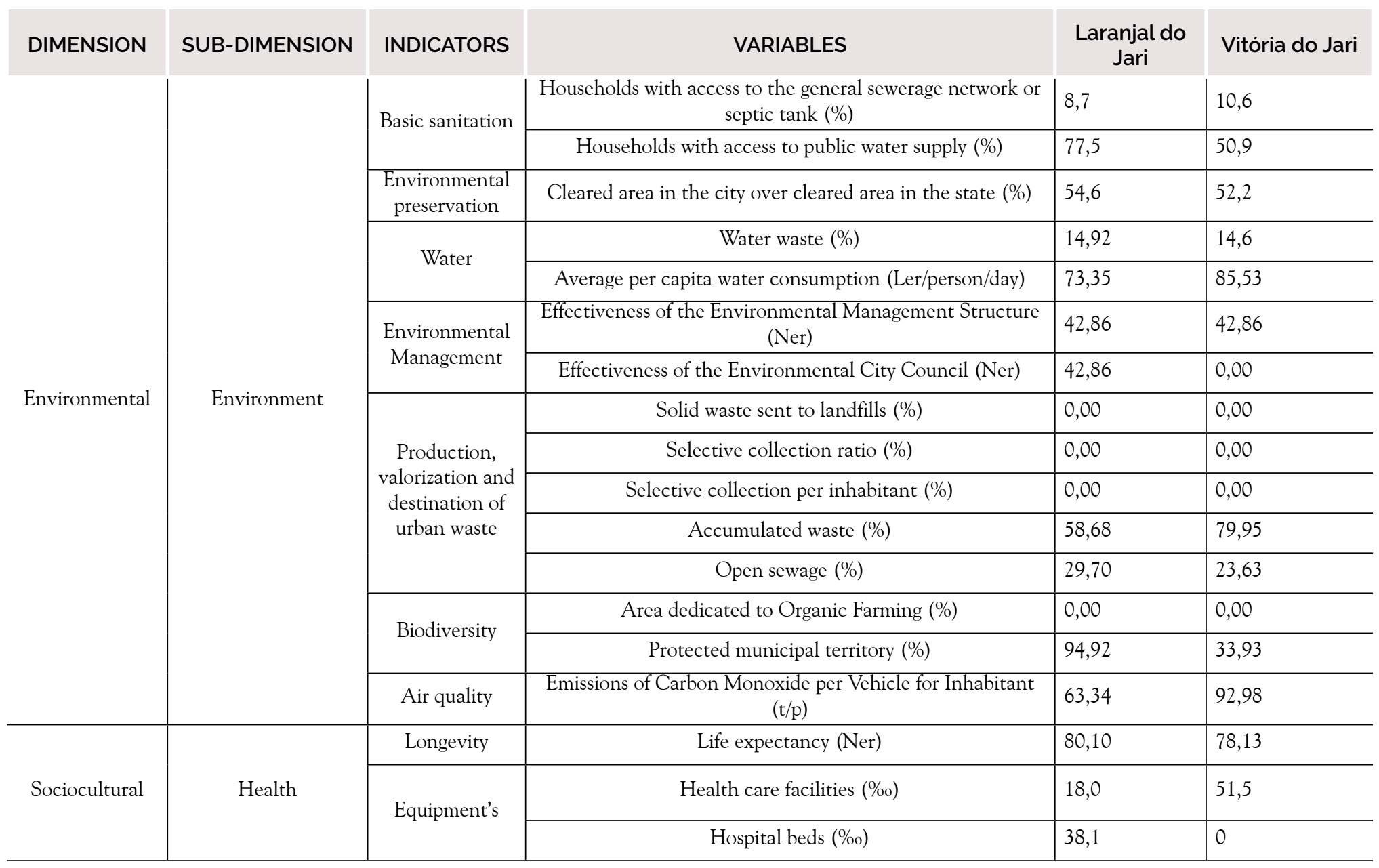




\begin{tabular}{|c|c|c|c|c|c|}
\hline DIMENSION & SUB-DIMENSION & INDICATORS & VARIABLES & $\begin{array}{l}\text { Laranjal do } \\
\text { Jari }\end{array}$ & Vitória do Jari \\
\hline \multirow{20}{*}{ Sociocultural } & \multirow{10}{*}{ Health } & \multirow{4}{*}{$\begin{array}{l}\text { Health and } \\
\text { wellness }\end{array}$} & $\begin{array}{l}\text { Mortality by Respiratory Disorders (100 thousand inhabi- } \\
\text { tants) }\end{array}$ & 90,4 & 79,51 \\
\hline & & & Mortality by Chronic Diseases (100 thousand inhabitants) & 85,3 & 93,1 \\
\hline & & & Obesity (\%) & 64,2 & 61,8 \\
\hline & & & Suicide (100 thousand inhabitants) & 97,6 & 91,49 \\
\hline & & \multirow{6}{*}{$\begin{array}{l}\text { Basic health } \\
\text { care }\end{array}$} & Malnutrition (\%) & 63,80 & 41,60 \\
\hline & & & Death by malnutrition (100 thousand inhabitants) & 97,6 & 87,39 \\
\hline & & & Maternal Mortality (100 thousand live births) & 97,5 & 96,40 \\
\hline & & & Child Mortality (\%o) & 46,4 & 40,8 \\
\hline & & & Hospitalizations for diarrhea (\%o) & 66,0 & 80,0 \\
\hline & & & Mortality by Infections Diseases (100 thousand inhabitants) & 94,7 & 95,7 \\
\hline & \multirow{6}{*}{ Education } & \multirow{3}{*}{ Schooling } & Literate population (\%) & 73,0 & 71,5 \\
\hline & & & People aged 25 and more with higher education (\%) & 32,6 & 24,1 \\
\hline & & & Illiteracy rate $(\%)$ & 77,3 & 70,56 \\
\hline & & \multirow{3}{*}{$\begin{array}{l}\text { Quality of } \\
\text { Teaching }\end{array}$} & Achievement index in basic education - IDEB $(0-10)$ & 36,5 & 33 \\
\hline & & & Middle School Dropout (\%) & 78,8 & 72,8 \\
\hline & & & High School Dropout (\%) & 57 & 47 \\
\hline & \multirow{2}{*}{ Gender } & \multirow{2}{*}{ Gender } & Gender pay gap (women / men) (\%) & 67,7 & 60,2 \\
\hline & & & Violence against women (100 thousand inhabitants) & 80,4 & 80,5 \\
\hline & Population & $\begin{array}{c}\text { Age structure of } \\
\text { population }\end{array}$ & Dependence ratio (\%) & 62,8 & 69,4 \\
\hline & Security & Crime & Number of deaths by firearm (100 thousand inhabitants) & 95,53 & 97,62 \\
\hline
\end{tabular}




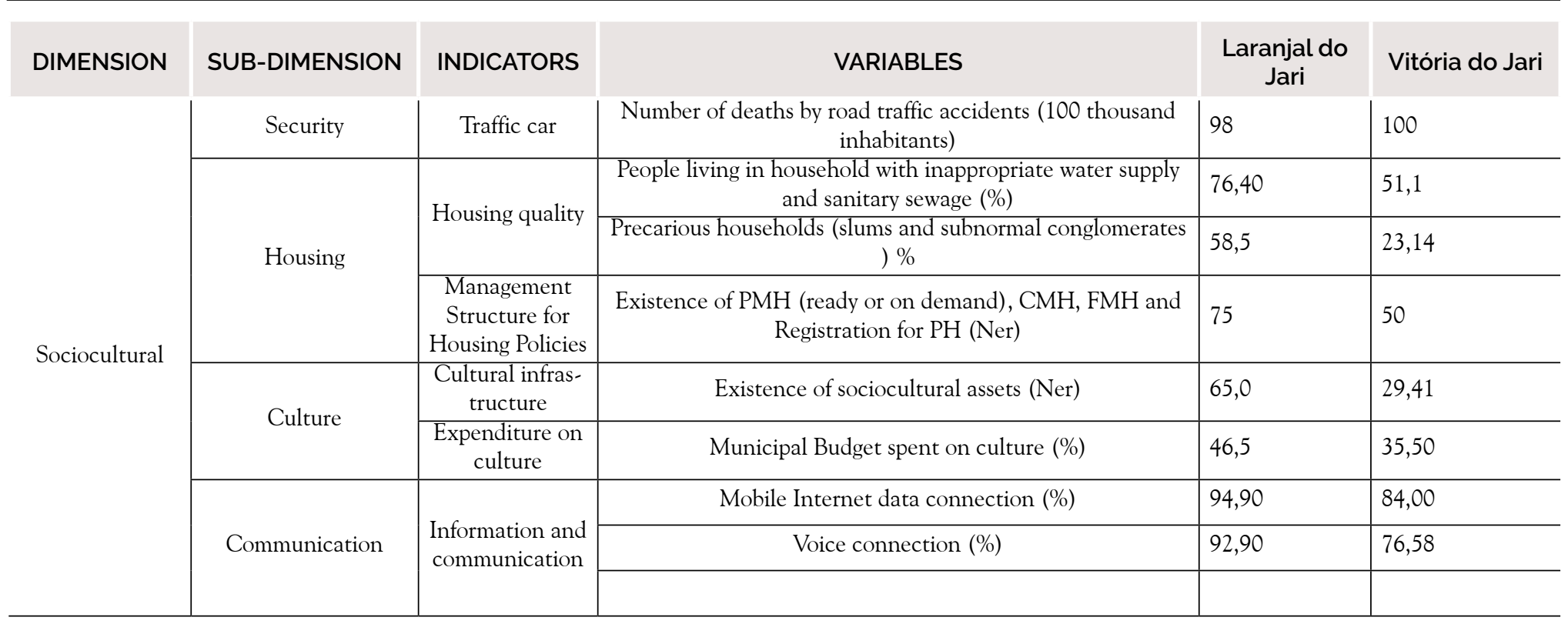

Source: The Authors, 2018 


\section{FINAL CONSIDERATIONS}

Sustainability indicators, pursuant to the recommendations of Agenda 21, in addition to the reflections of many authors about the context of large developments installed in the Amazon, were very important to demonstrate some of the most significant negative and positive impacts in the two municipalities at issue, Vitória and Laranjal de Jari.

With 34 indicators and 65 variables, it became clear that the greatest weakness for the two cities lies in the political-institutional dimension, and we could point out the major difficulties that these municipalities are experiencing. It should be noted that these countryside municipalities depend on large developments, which are the result of national policies for the Amazon.

However, both the economic and environmental dimensions also performed poorly. If we consider the qualitative scale (see footnote in methodology) and table 1 , we would have an "almost unsustainable" situation (from 20 to 40 points) for Vitoria do Jari and an "intermediate" situation for Laranjal do Jari, but it would be at the bottom of such range (from 40 to 60 points), with just over 45 points. In this sense, following the same logic, the political-institutional dimension is in the "unsustainable" range, in the case of Vitória do Jari, and in the "almost unsustainable" range, in the case of Laranjal do Jari, both cases with major weaknesses.

However, the socio-cultural dimension is the one that performs best in both municipalities, reaching the "almost sustainable" range (between 60 and 80 points), with Laranjal do Jari performing slightly better. When we think about the performance of this dimension, clearly better than the others, it is quite surprising that while the institutionalpolitical dimension perform poorly and the economic dimension perform on average, the socio-cultural dimension performs so well.

These performances show a contradiction that cannot be understood simply by indicators. As pointed out in this paper, the performance of some of the variables that make up the indicators of the socio-cultural dimension is high due to the fact that the values with lower performances are considerably higher in some municipalities. In that regard, it can be seen that, in a nation-wide context, the performance of the socio-cultural dimension is significant, although we understand that the same logic does not apply if we consider only the state of Amapá as, in fact, it was possible to observe in other studies (FERREIRA; TOSTES, 2014, 2017).

Finally, another aspect worth mentioning is the fact that the state of Amapa is one of the most environmentally preserved states in Brazil (72\%). When analyzing the amount of preserved areas in the municipalities at issue, we can see that these are highly preserved municipalities. The best example is the municipality of Laranjal do Jari with $94.92 \%$ of its area under environmental protection (Vitória do Jari has 33.39\%), however, it still has many issues, as shown by the indicators.

This level of preservation, in the case of Laranjal do Jari, leaves only a 5.08\% share of the territory for an effective municipal management, which corresponds to the urban area of the municipality. Thus, it can be seen that the overwhelming majority of 
the negative impacts are felt in the urban area, in these $5.08 \%$ of the municipality, which shows that urban areas need more attention and dedicated public policies to try to solve the negative impacts shown by the performance indicators.

\section{REFERENCES}

BARCELLOS, P. F. P.; BARCELLOS, L. F. P. Planejamento urbano sub perspectiva sistêmica: considerações sobre a função social da propriedade e a preocupação ambiental. Revista da FAE, Curitiba, v. 7, n. 1, p. 129-144, jan/jun 2004.

BELLEN, H. M. van. Desenvolvimento Sustentável: uma descrição das principais ferramentas de avaliação. Ambiente \& Sociedade, Vol. VII, N. 1, Jan./Jun., pp. 67-87, 2004.

BOSSEL, H. Indicators for Sustainable Development: theory, methods, applications. A report to the Balaton Group. Winnipeg, IISD, 1999.

BRAGA, T. M. et. al. Índices de sustentabilidade municipal: o desafio de mensurar. Discussion Text ner 225. Belo Horizonte: UFMG/Cedeplar, 2003.

BRAGA, T. M. et al. Índices de sustentabilidade municipal: o desafio de mensurar. Nova Economia, 14 (3), Setembro-Dezembro, pp. 11-33, 2004.

CHAGAS, M. A. A Consolidação da Fronteira da Preservação e as Cidades-Parques na Amazônia: O Caso do Vale do Jari, no Amapá. In: VII Encontro da Associação Nacional de Pós-Graduação e Pesquisa em Ambiente e Sociedade, Brasília, 2015.

COMISSÃO MUNDIAL SOBRE MEIO AMBIENTE E DESEVOLVIMENTO (CMMAD).

Nosso Futuro Comum. Rio de Janeiro: Editora da Fundação Getúlio Vargas, 1991.

CONFERÊNCIA DAS NAÇÕES UNIDAS SOBRE O MEIO AMBIENTE E DESENVOLVI-

MENTO (CNUMAD). Agenda 21. Brasília: Câmara dos Deputados. Coordenação de Publicações: Brasília, 1995. <http://bd.camara.gov.br/bd/handle/bdcamara/7706?show=full>. Accessed November 20, 2018.

FERREIRA, J. F. C. A Sustentabilidade do Alto Douro Vinhateiro: realidade ou utopia? Contributo para a avaliação e melhoria da sustentabilidade da região. PhD Thesis (Doutorado em Geografia e Planeamento Territorial), Faculdade de Ciências Sociais e Humanas (UNL), Lisboa, 2012.

FERREIRA, J. F. C. Avaliação da Sustentabilidade: Limites e Possibilidades no Alto Douro Vinhateiro, Portugal. Revista Sustentabilidade em Debate - Brasília, V. 4, n. 2 pp. 168-193, jul/ dez, 2013.

FERREIRA, J. F. C; TOSTES, J. A. Indicadores de sustentabilidade para aferição de impactos ambientais e urbanos nos municípios de Macapá e Santana (Amapá-Brasil). 3ํㅗeminário Internacional de Arquitetura Urbanismo e Design. Vol. II - As ordens do território, Eco-arquiteturas, Lisboa 13-15 de Outubro, pp. 276-287, 2014. 
FILOCREÃO, A. S. M. Agroextrativismo e capitalismo na Amazônia: as transformações recentes no agroextrativismo do sul do Amapá. PhD Thesis (Doutorado em Desenvolvimento Sustentável em Trópico Úmido) - Universidade Federal do Pará, Belém, 2007.

GIBSON, R. B. et al. Sustainability Assessment. Criteria and Processes. London: Earthscan, 2005.

GUIMARÃES, R. P.; FEICHAS, S. A. Q. Desafios na construção de indicadores de sustentabilidade. Ambiente \& Sociedade, Campinas, v. XII, n. 2, jul.-dez, pp. 307-323, 2009.

INSTITUTO BRASILEIRO DE GEOGRAFIA E ESTATÍSTICA (IBGE). Cidades» Amapá» Laranjal» estimativa da população 2016. < http://www.cidades.ibge.gov.br/xtras/temas. php?lang $=\& \operatorname{codmun}=160020$ \&idtema $=130 \&$ search $=$ amapa $\mid$ laranjal $\mid$ estimativa-da-populac ao-2016>. Accessed July 03, 2018.

KEMERICH, P. D. C.; RITTER, L. G.; BORBA, W. F. Indicadores de sustentabilidade ambiental: métodos e aplicações. Revista Monografias Ambientais - REMOA, V. 13, N. 5, Edição Especial LPMA/UFSM, pp. 3723-3736, 2014.

KERK, G. van; MANUEL, A. R. A comprehensive index for a sustainable society: The SSI the Sustainable Society Index. Ecological Economics, 66, pp. 228-242, 2008.

MARTINS, S. R. Desenvolvimento Sustentável: desenvolvendo a Sustentabilidade. 2004.

$<$ https://repositorio.ufsc.br/bitstream/handle/123456789/128116/DS\%20Sergio\%20Martins. doc? sequence $=4>$. Accessed November 20, 2018.

MASCARENHAS, A. et al. The role of common local indicators in regional sustainability assessment. Ecological Indicators, 10, pp. 646-656, 2010.

MAWHINNEY, M. Desenvolvimento Sustentável. Uma Introdução ao debate ecológico. São Paulo: Edições Loyola, 2005.

MINISTÉRIO DO MEIO-AMBIENTE. Download de dados geográficos.

<http://mapas.mma.gov.br/i3geo/datadownload.htm>. Accessed November 20, 2018.

PAIXÃO, E. S. B. Plano Diretor Participativo: análise das contribuições e alternativas para os problemas urbanos das áreas de várzea do município de Laranjal do Jari (AP). Master Thesis (Mestrado em Desenvolvimento Regional) - Fundação Universidade Federal do Amapá, Macapá, 2008.

PAIXÃO, E. do S. B. Questões socioambientais da cidade de Laranjal do Jari/AP: reflexões na perspectiva da educação popular. Revista de Gestão e Secretariado-GeSec, São Paulo, v. 7, n. 2, maio./ago., pp. 80-103, 2016.

PAIXÃO, E. S. B; TOSTES, J. A. Laranjal do Jari (estado do Amapá): Conflitos na gestão urbana de uma pequena cidade amazônica e as perspectivas a partir do Plano Diretor Participativo. La planificación territorial y el urbanismo desde el diálogo y la participación. Actas del XI Coloquio Internacional de Geocrítica, Universidad de Buenos Aires, 2-7 de mayo de 2010.

PORTO J. L. R. Amapá: Principais Transformações Econômicas e Institucionais (1943-2000). 
Macapá: SETEC. 2003.

PROGRAMA CIDADES SUSTENTÁVEIS. Metas de Sustentabilidade para os Municípios Brasileiros (Indicadores de Referência), 2012.

<Available at: www.cidadessustentaveis.org.br>. Accessed November 20, 2018.

RABELO, B. V. et al. Laranjal do Jari: Realidades que devem ser conhecidas. Macapá: IEPA, 2004.

RAMOS, T. B. Development of regional sustainability indicators and the role of academia in this process: the Portuguese practice. Journal of Clean Production, 17, p. 1101-1115, 2009.

RIBEIRO, A. L. Modelo de indicadores para mensuração do desenvolvimento sustentável na Amazônia. PhD Thesis (Doutorado em Ciências: Desenvolvimento Sustentável), Universidade Federal do Pará, NAEA, Belém, 2002.

ROBERTS, P. Evaluating Regional Sustainable Development: Approaches, Methods and the Politics of Analysis. Journal of Environmental Planning and Management, Vol. 40, No. 4, pp. 515-532, 2006.

ROLDÁN, A. B.; VALDÉS, A. S. Proposal and application of a Sustainable Development Index. Ecological Indicators, 2, pp. 251-256, 2002.

SANTOS, D. et al. Índice de Progresso Social na Amazônia Brasileira. IPS Amazônia 2014. Belém-Pa: Imazon, 2014

SIENA, O. Método para avaliar o progresso em direção ao desenvolvimento sustentável. $\mathrm{PhD}$ Thesis (Doutorado em Engenharia de Produção), Universidade Federal de Santa Catarina, Florianópolis, 2002.

SILVA, A. S.; SOUZA, J. G.; LEAL, A. C. Qualidade de vida e meio ambiente: experiência de consolidação de indicadores de sustentabilidade em espaço urbano. Revista Sustentabilidade em Debate - Brasília, V. 3, n. 2 pp. 177-196, jul/dez, 2012.

SILVA, C.. L. (Org.). Desenvolvimento Sustentável. Um Modelo analítico integrado e adaptativo. Petrópolis: Editora Vozes, 2006.

SILVA, F. C.; AMIN, M. M.; NUNES, S. F. (Org.). Sustentabilidade dos Municípios da Amazônia. Belém: NAEA, 2015.

SPANGENBERG, J. H. et al. Towards indicators for institutional sustainability: lessons from an analysis of Agenda 21. Ecological Indicators, 2, pp. 61-77, 2002.

TOSTES, J. A.; FERREIRA, J. F. C. Avaliação da Sustentabilidade na Amazônia: a mesorregião Norte do Amapá. G\&DR, vol. 13, n. 1, Jan-abr/2017, Taubaré, SP, Brasil, pp. 198-223, 2017.

TOSTES, J. A. Planos Diretores do Estado do Amapá. A experiência do município de Laranjal do Jari: uma contribuição para o desenvolvimento regional. Macapá: UNIFAP, 2009.

TOSTES, J. A. Transformações urbanas das pequenas cidades amazônicas (AP) na Faixa de Fronteira Setentrional. Rio de Janeiro: Publit, 2012. 
VALE, F. A. F; TOLEDO, P. M.; VIEIRA, I. C. G. Análise comparativa de indicadores de sustentabilidade entre estados da Amazônia Legal. Sustentabilidade em Debate, Brasília, v. 9, n. 1, pp. 214-231, 2018.

WHEELER, S. Planning for Sustainability. Creating livable, equitable, and ecological communities. Oxon: Routledge, 2004. 
José Francisco de Carvalho Ferreira

$\square$ zfcofer@gmail.com

ORCiD: https://orcid.org/0000-0001-8266-166X

Jacklinne Matta Corrêa

$\square$ jacklinne.matta1@gmail.com

ORCiD: https://orcid.org/0000-0003-4514-1205

\section{Jodival Maurício Costa}

$\square$ jodival.costa@gmail.com

ORCiD: https://orcid.org/0000-0003-4365-36X
Submitted on: 29/12/2018

Accepted on: 25/02/2020

2020;23:e03082

How to cite: FERREIRA, J. F. C.; CORREAA J. M.; COSTA, J. M. SUSTAINABILITY ASSESSMENT OF JARI VALLEY- AMAPÁ, AMAZON: LARANJAL AND VITÓRIA DO JARI. Ambiente \& Sociedade. São Paulo, v. 23, p. 1-24, 2020. 


\title{
AVALIAÇÃO DA SUSTENTABILIDADE DO VALE DO JARI - AMAPÁ, AMAZÔNIA: LARANJAL E VITÓRIA DO JARI
}

\author{
José Francisco de Carvalho Ferreira \\ Jacklinne Matta Corrêa \\ Jodival Maurício Costa
}

São Paulo. Vol. 23, 2020

Artigo Original
Resumo: As problemáticas de natureza regional/local requerem o uso de ferramentas que analisem os processos relacionados ao modelo de desenvolvimento, compatíveis aos princípios do desenvolvimento sustentável. Neste contexto, pesquisas sobre a sustentabilidade ganham espaço no debate do desenvolvimento, a partir da utilização de indicadores. Embora escassas no âmbito do Estado do Amapá, as avaliações da sustentabilidade podem ressaltar os impactos que emergem no entorno de grandes projetos privados instalados na Amazônia. Nesse sentido, este artigo buscar aferir os níveis de sustentabilidade de Laranjal e Vitória do Jari, recorrendo ao uso de indicadores que incorporam diversas dimensões e aspectos. Metodologicamente, utiliza-se indicadores recolhidos de fontes oficiais, tratados e normalizados por metodologia própria, da qual resultou uma pontuação, que assinala o progresso municipal em direção ao desenvolvimento sustentável. Os resultados assinalam que os dois municípios têm fracos desempenhos que comprometem a sua sustentabilidade municipal em direção à Agenda 2030.

Palavras-chave: Avaliação da Sustentabilidade. Amazônia Sustentável. Laranjal do Jari. Vitória do Jari.

Como citar: FERREIRA, J. F. C.; CORRÊA, J. M.; COSTA, J. M. AVALIAÇÃO DA SUSTENTABILIDADE DO VALE DO JARI - AMAPÁ, AMAZÔNIA: LARANJAL E VITÓRIA DO JARI. Ambiente \& Sociedade. São Paulo, v. 23, p. 1-25, 2020. 


\title{
EVALUACIOON DE LA SOSTENIBILIDAD DEL VALLE DE JARI - AMAPÁ, AMAZONIA: LARANJAL E VITÓRIA DO JARIS
}

\author{
José Francisco de Carvalho Ferreira \\ Jacklinne Matta Corrêa \\ Jodival Maurício Costa
}

São Paulo. Vol. 23, 2020

Artículo original
Resumen: Las problemáticas de naturaleza regional/local requieren el uso de herramientas que analizan los procesos relacionados con el modelo de desarrollo, compatibles con los principios del desarrollo sostenible. En este contexto, investigaciones sobre la sostenibilidad ganan espacio en el debate del desarrollo, a partir de la utilización de indicadores. Aunque escasas en Amapá, las evaluaciones de la sostenibilidad pueden resaltar los impactos que emergen en el entorno de grandes proyectos privados instalados en Amazonia. En este sentido, este artículo busca evaluar los niveles de sostenibilidad de Laranjal y Vitória de Jari, recurriendo al uso de indicadores que incorporan diversas dimensiones y aspectos. Metodológicamente, se utilizan indicadores recogidos de fuentes oficiales, tratados y normalizados por metodología propia, de la cual resulta una puntuación, que señala el progreso municipal hacia el desarrollo sostenible. Los resultados señalan que los dos municipios tienen débiles desempeños que comprometen su sostenibilidad municipal hacia la Agenda 2030.

Palabras-clave: Evaluación de la sostenibilidad. Amazonia Sostenible. Laranjal de Jari. Vitória de Jari.

Como citar: FERREIRA, J. F. C.; CORREAA, J. M.; COSTA, J. M. EVALUACÍON DE LA SOSTENIBILIDAD DEL VALLE DE JARI - AMAPÁ, AMAZONIA: LARANJAL E VITÓRIA DO JARI. Ambiente $\&$ Sociedade. São Paulo, v. 23, p. 1-25, 2020. 